\title{
Setting the scene for alternative futures for European Union's foreign policy 2025
}

\author{
Monika Sus ${ }^{\mathrm{a}, \mathrm{b}, *}$ \\ ${ }^{\text {a }}$ Hertie School of Governance, Germany \\ ${ }^{\mathrm{b}}$ European Union Institute, Italy
}

\section{A R T I C L E I N F O}

\section{Keywords:}

EU foreign policy

Foresight studies

Multiple scenario generation

Strategic thinking

\begin{abstract}
A B S T R A C T
The purpose of this collection is to provide a footing for charting the course of policy actions relating to EÚs future role in the world by a comprehensive and systematic analysis of driving forces that will shape the relations between the European Union and its neighbours as well as strategic partners. The included papers offer a far-reaching overview of the EÚs external relations in 2025 and allow conclusions to be drawn that can inspire the shaping of its foreign and security policy. The premise of the special issue is the assumption that only by proactively facing challenges ahead, will the European Union have a chance maintain its impact on the global order. Thus, this collection aims at making a contribution to define EU's future-oriented interests and to tackle the question of how these interests can be reconciled with values that the Union attempts to project and protect.
\end{abstract}

\section{Introductory remarks}

Over the last decade 'uncertain' might very well have been the most common adjective used to describe the future of the European Union. Political and economic stability, liberal order based on the rule of law, pluralism and the absence of major conflicts on EÚs territory and in its neighbourhood are not taken for granted any longer. The unthinkable has become thinkable - after the British referendum even an exit of a country from the EU is no longer taboo. Among all political and economic turmoil that has pulled the Union apart and divided it internally in the last decade, Brexit has delivered the coup de grâce. As the European Union's Global Strategy (EUGS) rightly noted, "We live in a world of predictable unpredictability. We will therefore equip ourselves to respond more rapidly and flexibly to the unknown lying ahead (EEAS, 2016, p. 46). The first part of the quotation is now to be taken for granted. There seems to be consensus that existential pressure from both inside (growing political polarisation, illiberal tendencies across the Member States, domestic terrorism, fiscal instability) and outside (Daesh, refugee and migration crisis, geopolitical ambitions of Russia, precariousness of US President Trump's policy) will transform the European project. However, the second part of the quotation presents a profound challenge for the European Union and its Member States. Beyond any doubt, navigating Europe through stormy waters requires a more rapid and flexible response to unexpected events, yet the ability of strategic thinking was never a particular strength of the Union. The evidence of strategic thinking was rather rare and so far, the European Union has tended to react to crisis rather than to act in advance of happenings. As a result, it usually gets caught by surprise. The Arab Spring, the British decision to leave the Union, the Russian annexation of Crimea and the recent migration waves to Europe offer illustrative examples.

To swing the trend around and act ahead of crisis, a systematic analysis of challenges that influence the development of the European project, both internally and externally, is called for. This special issue aims at tackling this urgency. Advancing the

\footnotetext{
* Correspondence to: Hertie School of Governance, Friedrichstraße 180, 10117, Berlin, Germany.

E-mail address: sus@hertie-school.org.
} 
outcomes of the Dahrendorf Foresight Project (Sus, 2016), this collection applies the Multiple Scenario Generation approach and puts forward plausible developments of the relations between the EU, its strategic partners (United States and China) and its neighbours (Turkey, Libya as a country representative for the region, Ukraine and Russia) as well as the United Kingdom in the aftermath of the Brexit. The overall aim of this special issue is to challenge existing assumptions and identify novel lines of inquiry with regard to the EU's foreign policy in ten years' time. In order to raise awareness for what the future may unfold, the contributions reflect on driving forces that are likely to shape the EU's relationship with other countries and indicate necessary steps to be taken into consideration in formulating and implementing the Union's foreign policy.

The point of departure for this collection is constituted by the belief of its authors that the European Union needs a strong visionary leadership who will be able to deliver anticipatory governance and improve the EU performance both internally and externally. The need for the EU to act strategically in order to endure and play a global role seems to become a common narrative in the broad European foreign and security community. It is reflected in a growing number of foresight projects across the continent ${ }^{1}-$ future studies, which for decades have been rather a domain of a limited community of practice, enjoy increasingly growing attention among European policy-makers, experts and scholars (Sus, 2017, p. 116-117). The European Commission also actively engaged in foresight thinking and since the beginning of 2017 it developed two proposals with alternative futures for the general scenarios for the development of the European Union (European Commission, 2017a) and for the enhancement of its security and defence policy (European Commission, 2017b).

There are two main characteristics that distinguish the particular foresight exercise presented in this collection from the others. First of all, it is its comprehensiveness - it presents alternative futures for the relationship with the Union's five most important neighbours and partners and it is complemented by a paper on the future relations between the EU and United Kingdom after Brexit. Thus, the collection offers a far-reaching overview of the EÚs external relations in 2025 and allows conclusions to be drawn that can inspire the shaping of its foreign and security policy. Second of all, it is the nature of the process along which the scenarios were developed. The multistep process took over nine months and engaged a great variety of participants - 80 experts, officials and academics from European and non-European countries, in order to include the outside-in perspective (Sus, 2016, p. 59-60). This approach led not only to surprising and innovative, but above all to scientifically robust, plausible scenarios complemented with indicators to monitor as early-warning signals. Such an outcome would not have been possible to achieve during short scenario sessions within a group of like-minded people who would have been more likely to engage in streamlined groupthink.

\section{Foresight and future studies as a conceptual tool in international relations (IR)}

The debate about the theoretical background of foresight and future studies has been going on for a few decades but the discipline of future studies is not that well established compared with other mainstream fields such as sociology or political science (Öner, 2010; Ahlqvista \& Rhisiartb, 2015; Bell, 2002). There is, however, a range of distinctive features that distinguish this discipline from others (Bell, 2002). Scenario approach is one of the core key concepts shared by scholars working in this field. According to Peter Schwartz, one of the leading futurists worldwide, scenarios can be defined as 'stories about the way the world might turn out tomorrow, stories that can help us recognize and adapt to changing aspects of our present environment' (Schwartz, 1991, p. 3). The goal of generating scenarios is to deliver a set of alternative futures based on systematic and rigorous analyses of global trends, common assumptions and key forces behind a given issue and thereby to widen the perspective of policymakers. The world will remain a place of high uncertainty, however scenario methodology helps to keep strategic surprises to a minimum and is to be preferred over waiting passively for future events to unfold. As Gnad and Burrows present in the contribution to the special issue, it is not mere forecasting based on a linear analysis of current patterns nor simple hypothesis-based expert predictions, but rather consists of various qualitative and quantitative approaches, including the generation of multiple scenarios, which is one of the most promising, especially in cases of great uncertainty (Pherson, 2015, pp. 34-40; Popper, 2008, pp. 44-90).

Furthermore, foresight studies and Multiple Scenario Generation are useful instruments in the conceptual toolbox of IR discipline that allow us to identify and to examine crucial factors and forces that determine the international global order. The value of scenarios for IR and especially for its sub discipline, Foreign Policy Analysis (FPA), is threefold. First, alternative futures widen the perspective to cover a range of unexpected yet plausible outcomes based on various pairings of key drivers. Scenarios break the assumption that the future will resemble the past and that change is only gradual. The explanatory power of scenarios can therefore offer a useful lens in the FPA.

Second, scenario methodology facilitates contrarian thinking and undermines the groupthink that often occurs in homogeneous environments. Foreign policy elites of the past have shown that they are not immune to its sometimes-fatal consequences. In light of the uncertainty of foreign policy of states and organisations and the existence of diverse factors of influence, it seems to be a must for foreign policy experts to go beyond conventional wisdom and extrapolations of contemporary patterns in order to arrive at possible future courses of action. In addition to that, scenario methodology can answer to the criticism of scholars who argue that most scholarship about the future of European foreign policy remains 'too self-absorbed, looking at Europe through European eyes in a well-shaped European mirror' (Mayer, 2008, p. 8). As Dijkstra and Vanhoonacker rightly noted (2016, pp. 1-7), the outside-in perspective needs to be underpinned with theories in order for it to become an attractive driver for a new research projects. The scenario approach by including the outside-in perspective and by looking at the bilateral relations between the EU and the neighbours or global powers from their perspective of the partner countries, seems to be a valuable tool in this regard.

\footnotetext{
${ }^{\mathbf{1}}$ For an overview of the outcomes of foresight projects across, see the Open Repository Base on International Strategic Studies: http://espas.eu/orbis/.
} 
Third, foresight methodology in general and scenario approaches in particular offer a viable tool to bridge the growing gap between academia and policy-making. A notable concern of many prominent social scientists, the "cult of irrelevance" (Walt, 2009) highlights the chasm between abstract academic research and the needs of decision makers to obtain policy relevant advice and is damaging for both sides. Theory is an essential tool for evaluating the impact of policies, explaining causal developments and identifying directions of change. Voices are becoming louder that propose to enhance the policy relevance of research in IR and to communicate outcomes and implications of the research findings to policymakers in a comprehensible manner (Desch, 2009; Nye, 2009). There are also calls to reintegrate practice into the analyses of global politics (Neumann, 2002). Scenario methodology is one of the most effective research techniques to link academic theories with empirical data in order to understand future world events more fully, as it combines in-depth analysis with policy relevant implications or even recommendations. Foresight studies correspond well with the thinking of scholars with an eclectic approach (Katzenstein \& Okawara, 2001-2002, pp. 153-185) and with those who apply more pragmatism in IR reasoning (Friedrichs \& Kratochwil pp. 701-731). Given the lack of adequate methodology in the field of IR that would allow for analysing future events, a systematic scenario methodology could contribute to filling the gap.

Having in mind the potential of foresight studies for IR and FPA, this collection hopes to contribute to the further popularizing of this instrument not only as a tool used to advise policy-makers, but also as a methodological approach for academic purposes.

\section{How might the EU external relations unfold in 2025?}

The special issue comprises seven contributions. In the opening article, Gnad and Burrows deliver the methodological background for the succeeding papers and present a four-step Multiple Scenario Generation. This systematic tool was followed by the authors of the collection for the development of their narratives of alternatively plausible futures in the EU's external relations. By offering examples from the application of scenarios in US policy-making, Gnad and Burrows also argue that foresight and future studies should not only be seen as an academic exercise, but should also be available as policy tools for decision-makers to face the widespread feeling of uncertainty in today's world.

The following two articles present alternative futures for the relationship between the European Union and two global powers: United States and China. The point of departure for scenarios developed by Kaufmann und Lohaus lies on the assumption that in the era of President Trump, political goals and principles once shared on both sides of the Atlantic appear to be up for renegotiation. However, the uncertainty about US policy creates a window of opportunity for the EU to rethink its values, interests and instruments at its disposal. Paraphrasing Churchill's famous statement, the Union should not waste such a crisis but turn it into an opportunity to reform its policy instruments, the contribution of Gabriel and Schmechler points to two particularly important key drivers for the future EU - China relations: the green economy and the technological leadership. They argue that the Union is able to act from a position of a genuine strength when the Member States provide a strong mandate based on shared interests. Their scenarios also revealed a blank spot in forward-looking thinking about the bilateral relations between China and the EU - the significant role of the US that impacts this relation and must be taken into consideration.

The next three papers deal with alternative futures for the relationship between the EU and its neighbours. Davydchyk, Mehlhausen and Priesmeyer-Tkocz unpack the tense relations between Ukraine and the European Union and perceive Russian influence in the region as one of the main given factors for the analysis. Along two main drivers - professionalization of Ukrainian politics and political culture as well as EU coherence in its Eastern policy, they put forward four scenarios that might also be instructive for studies of Moldova and Georgia as these countries face comparable challenges of transformation, integration with the EU and economic interdependence with Russia. Stupen, in turn, paints a picture of the relations between EU and Libya in the aftermath of the Arab Spring. By taking into account that Libya's turbulent post-revolutionary period has concomitantly seen a relative absence of Europe after 2011 and that the EU's reaction for the start of the second Libyan civil war in 2014 was confusingly divisive, the author presents four scenarios for the future bilateral relationship and identifies two areas of potential cooperation migration and the fight against terrorism. A comprehensive analysis of the possible future developments between EU and Turkey follows. Haferlach, Tekin and Wódka argue that foresight helps avoid prejudging the future of this ever-tense relationship and point to areas where functional cooperation between both partners could be possible, such as migration and asylum, which currently represents the glue of the bilateral relationship, but also the customs union or energy policy. However, the prospects depend from the internal developments in the country as well as from Ankara's policy towards the neighbourhood.

The final contribution written by Henökl was not originally planned to be a part of the collection, since it was not developed within the Dahrendorf Foresight Project. However, after the Brexit vote, we decided that to complement the special issue with the paper since UK's withdrawal from the Union will certainly impact the EU's foreign policy 2025. Therefore, the last paper deals precisely with the future relationship between the two parties and tries to assess Brexits consequences for Uniońs external action. In his scenarios, the author focuses in particular on the possible future outcomes of the cooperation between the EU and UK within the development cooperation. He also argues that since scholars do not have an appropriate toolkit available to analyse what is occurring directly in front of their eyes, the scenario approach helps to fill the gap. By taking a forward-looking perspective, it offers inspiring insights.

\section{Conclusions}

The alternative futures for the EU foreign policy 2025 offer an attempt to deconstruct the future in a systematic way, to inspire decision-makers and scholars to think differently about the Union's future role in the world and to recalibrate the instruments and policies that will probably be required in order to face the challenges ahead. However, all scenarios offer a simplification of reality. 
Hence, they must not be perceived as offering ready solutions; rather, they serve as food for thought that should be helpful in strategic thinking and planning. Since the world is rapidly changing and the economic and political balance of powers is shifting, the cost of inaction for the European Union will be extremely high and might endanger its endurance. Therefore, the EU needs to move from its critical juncture position, where it seems to be stuck since the economic crisis blew up, and throw the weight of strategic thinking and coherent political vision beyond its economic potential in order not to be marginalised in the world affairs. This constitutes the first main conclusion of the collection.

The second conclusion results from the fact there is one key-driver that has been identified by all papers as decisive for EU's foreign policy 2025-the cohesiveness of this policy (Stupen) understood also as the capacity for collective action (Kaufmann \& Lohaus) or as coherence in EU foreign policy in terms of the ability to speak with one voice (Davydchyk Mehlhausen \& Priesmeyer-Tkocz) and While this appeal belongs to common knowledge, it makes it not less essential. On the contrary, it points to the necessity of recalibration of the mechanisms and instruments within the Union's external policy. One can argue that the long-standing move towards a more cohesive foreign policy has gained momentum due to a series of conductive factors that are visible right now. First of all, the interest of the Member States for enhancement of security and defense policy, expressed by putting this topic on the top of the agenda of European Council within the last year (European Parliamentary Research Service pp. 6-9, 17-21) as well as by pursing with the implementation of the EUGS, seems to be distinct. Secondly, the public support more integration of security and defence policy has been constantly above 70\% since 1999 (European Commission Public Opinion, 2017) and the support for more common foreign policy has been enjoyed a similar popularity (Eurobarometer, 2017, p. 8). The strong support of European citizens towards further integration in this field combined with common threat perception - according to the recent Pew Research Centre's study 74\% Europeans are afraid of ISIS, 64\% of climate change and 54\% of cyberattacks (Poushter \& Manevich 2017, p. 7), deliver a clear signal for the policymakers towards the enhanced cooperation within foreign, security and defence policies. Thirdly, due to the successful entrepreneurship of High Representative Federica Mogherini, who uses her multiple institutional and political hats to get on board not only the national capitals but also the European Commission, the EUGS has not become another empty shell but is being implemented (EEAS, 2017). The on-going execution of the strategic provisions arouse expectations that the European foreign policy community (in Brussels and in national capitals) sees the urgency to act upon the reformulation of this policy area. However, equally important as the concrete steps such as activation of the battle groups, launch of a European Defence Fund or moving towards the Permanent Structured Cooperation, is the bigger perspective and an answer to the question: where does the European Union want to go? How does it want to look like and act in a global scene in a decade? What are the values and interests that the Union would like to promote via its policies and towards its neighbours and partners? Is the EU's foreign policy equipped with proper instruments to pursue this vision? These questions has been raised in the EUGS but there is need to for a serious debate among both the national leaders and the officials in Brussels. As it was mentioned by the contributors to the collection, Brexit and the uncertainties about the future the transatlantic alliance can be perceived as a window of opportunity to reform the EU's foreign policy and missing such a chance would further undermine Union's position in the world. At the end, "the onus of improving European security lies first of all in European hands" (European Commission 2017, p. 7).

Looking at the presented alternative futures, one can easily argue that the number of 'unknown unknowns' will probably be growing anyway and the EU's relations with neighbours and world powers such as China and USA will remain to be turbulent. However, while remaining humble about the probability of the scenarios, foresight studies might certainly be helpful to be prepared for at least some of the unexpected events and do not take chances to have the EU course be corrected by others or by accidents as it happened in the recent decade.

\section{Acknowledgements ${ }^{2}$}

I would like to express my deepest gratitude to all scholars, experts, policy makers and officials who participated in the Dahrendorf Foresight Project. Their profound expertise and readiness to engage with the Multiple Scenario Generation were the precondition for the collection. My gratitude goes also to anonymous reviewers of the papers and to the editorial team of "Futures" who facilitated the publication process as well as to Alexis Heede, who provided exceptional proofreading and editing of the texts. The collection would not have been possible without the Stiftung Mercator, which generously provided financial resources for the project. Last but not least, I am deeply grateful to Professor Helmut K. Anheier, President of the Hertie School of Governance and Gesa-Stefanie Brincker, Dahrendorf Project Manager, who offered their relentless support and inspiration. All faults and oversights remain my own.

\section{References}

Öner, M. A. (2010). On theory building in Foresight and Futures Studies: A discussion note. Futures, 42, 1019-1030.

Ahlqvista, T., \& Rhisiartb, M. (2015). Emerging pathways for critical futures research: Changing contexts and impacts of social theory. Futures, 71, 91-104. Bell, W. (2002). A community of futurists and the state of the futures field. Futures, 34, 235-247.

Desch, M. (2009). 'Professor smith goes to washington', notre dame magazine. Spring. [Available at] http://magazine.nd.edu/news/11174-professor-smith-goes-towashington/.

Dijkstra, H., \& Vanhoonacker, S. (2016). Why study EU foreign policy at all? A response to Keuleers, Fonck and Keukeleire. Cooperation Conflict, 52(2), 280-286. http://dx.doi.org/10.1177/0010836716682393.

EEAS (2016). Shared vision, common action a stronger europe. a global strategy for the european union's foreign and security policy. [Available at] http://eeas.europa.eu/

\footnotetext{
${ }^{2}$ The author also acknowledges the support of the National Research Council (along the project decision: DEC-2013/09/B/HS5/01356).
} 
archives/docs/top_stories/pdf/eugs_review_web.pdf.

EEAS (2017). From shared vision to common action: Implementing the EU global strategy year 1. [Available at] https://europa.eu/globalstrategy/sites/globalstrategy/files/ full_brochure_year_1. pdf.

Eurobarometer, Standard Eurobarometer 87, May 2017. [Available at] http://ec.europa.eu/commfrontoffice/publicopinion/index.cfm/Survey/getSurveyDetail/ instruments/STANDARD/surveyKy/2142.

European Commission Public Opinion (2017). Public Opinion and a common defence and security policy among Member States. [Available at:] http://ec.europa.eu/ commfrontoffice/publicopinion/index.cfm/Chart/getChart/chartType/lineChart/themeKy/29/groupKy/181/savFile/195.

European Commission (2017a). White Paper of the Future of Europe. Reflections and scenarios for the EU27 by 2025. [Available at:] https://ec.europa.eu/commission/ sites/beta-political/files/white_paper_on_the_future_of_europe_en.pdf.

European Commission (2017b). Reflection paper on the future of european defence. [Available at:] https://ec.europa.eu/commission/sites/beta-political/files/reflectionpaper-defence_en.pdf.

European Parliamentary Research Service (2017). European parliamentary research service (2017) the european council in 2016. overview of decisions and discussions [Available at:] http://www.europarl.europa.eu/RegData/etudes/IDAN/2017/603249/EPRS_IDA(2017)603249_EN.pdf.

Friedrichs, J., \& Kratochwil, F. (2009). On acting and knowing: How pragmatism can advance international relations research and methodology. Int. Organ. 63(4), 701-731. http://dx.doi.org/10.1017/S0020818309990142.

Katzenstein, P. J., \& Okawara, N. (2001). Japan,A sian-Pacific security, and the case for analytical eclecticism. Int. Secur. 26(3), 153-185. http://dx.doi.org/10.1162/ 016228801753399754.

Mayer, H. (2008). The long legacy of Dorian Gray: Why the European Union needs to redefine its role in global affairs. J. Euro. Integr. 30, 7-25.

Neumann, I. B. (2002). Returning practice to the linguistic turn: The case of diplomacy. Millennium - J. Int. Stud. 31(3), 627-651.

Nye, J. S., Jr. (2009). Scholars on the sidelines. [Washington Post, 13 April.].

Pherson, R. (2015). Handbook of analytic tools \& techniques. Washington: Pherson Associates.

Popper, R. (2008). Foresight methodology. In L. Georghiou, H. Cassingena, J. Keenan, \& I. Miles Popper (Eds.). The handbook of technology foresight. concepts and practices (pp. 44-90). Cheltenham: Edward Elgar.

Poushter, J., \& Manevich, D. (2017). Globally, people point to ISIS and climate change as leading security threats. concern about cyberattacks, world economy also widespread. Pew Research Center.

Schwartz, P. (1991). The art of the long view: Planning for the future in an uncertain world. NJ: Currency Doubleday.

European union in the world 2025. scenarios for EU relations with its neighbours and strategic partners. hertie school of governance and LSE ideas: Dahrendorf analysis. In M. Sus, \& F. Pfeifer (Eds.). . [Available at:] http://www.dahrendorf-forum.eu/wp-content/uploads/2016/05/Dahrendorf_Analysis_European-Union-in the-World-2025.pdf.

Sus, M. (2017). Towards the european union's foreign policy 2025-Taking stock of the dahrendorf foresight project. Global Policy, 8(4), 115-125. http://dx.doi.org/10. $1111 / 1758-5899.12438$.

Walt, S. (2009). The cult of irrelevance, foreign policy, 15 april. [Available at:] http://foreignpolicy.com/2009/04/15/the-cult-of-irrelevance/. 